\title{
Undergraduate students in orthopedic nursing care ${ }^{1}$
}

\author{
Lys Eiras Cameron² \\ Sílvia Teresa Carvalho de Araújo ${ }^{3}$
}

\begin{abstract}
This study identifies some undergraduate nursing students' imaginary manifestations concerning themselves and care delivered to patients with orthopedic and/or trauma disorders. The Social Poetics method was used and the research group was composed of 15 undergraduate students. Only the categories and subcategories exclusively related to the "student" are presented in this paper. Data revealed that care provided by orthopedic nursing students is the result of a care relationship that emerges from their sensitivity toward patients and their own knowledge, skills and attitudes. The orthopedic treatment, equipment and procedures, to which patients are submitted, cause important emotional distress for students, empathic behavior and encourage them to search for ways to minimize their patients' pain. All the aspects that permeate care provided by orthopedic nursing students should be identified in order to enable reassessment of the teaching-learning process.
\end{abstract}

Descriptors: Orthopedic Nursing; Nursing Care; Education, Higher.

\footnotetext{
${ }^{1}$ Paper extracted from Doctoral Dissertation "O imaginário do estudante de graduação sobre a assistência em Enfermagem TraumatoOrtopédica", presented to Escola de Enfermagem Anna Nery, Universidade Federal do Rio de Janeiro, RJ, Brazil.

${ }^{2}$ RN, Ph.D. in Nursing, Adjunct Professor, Escola de Enfermagem Anna Nery, Universidade Federal do Rio de Janeiro, RJ, Brazil. E-mail: lyscameron@gmail.com.

${ }^{3}$ RN, Ph.D. in Nursing, Associate Professor, Escola de Enfermagem Anna Nery, Universidade Federal do Rio de Janeiro, RJ, Brazil. E-mail: stcaraujo@gmail.com.
} 


\section{O estudante de graduação e a assistência em enfermagem tráumato- ortopédica}

O objetivo deste estudo foi apresentar algumas manifestações do imaginário do estudante de graduação em Enfermagem, sobre si mesmo, ao prestar assistência ao paciente com distúrbios tráumato-ortopédicos. Utilizou-se o método Sociopoético e o grupo pesquisador era composto por quinze estudantes de graduação. Neste artigo estão apresentadas somente as categorias e subcategorias relacionadas exclusivamente ao "estudante". Os dados demonstram que a assistência prestada pelo estudante em enfermagem tráumato-ortopédica é produto de uma relação de cuidado, que emerge através da sua sensibilidade para com seu paciente, e de seus próprios conhecimentos, habilidades e atitudes. O tratamento, os aparatos e os procedimentos ortopédicos aos quais o paciente é submetido geram, no estudante, importante desgaste emocional, comportamento empático e a busca por mecanismos que minimizem a dor do outro. Todos os aspectos que permeiam a assistência discente em Enfermagem TráumatoOrtopédica necessitam ser conhecidos, para permitir reavaliação do processo ensinoaprendizagem.

Descritores: Enfermagem Ortopédica; Cuidados de Enfermagem; Educação Superior.

\section{El estudiante de graduación y la asistencia de enfermería ortopédica}

El objetivo de este estudio es presentar algunas manifestaciones del imaginario del estudiante de graduación en Enfermería, sobre sí mismo, al prestar asistencia al paciente con disturbios traumatológicos ortopédicos. Se utilizó el método Socio-Poético; y el Grupo-Investigador fue compuesto por quince estudiantes de graduación. En este artículo se presentan solamente las categorías y subcategorías relacionadas exclusivamente al "estudiante". Los datos demuestran que la asistencia prestada por el estudiante de enfermería en traumatología y ortopedia, es producto de una relación de cuidado que emerge a través de su sensibilidad para con su paciente y de sus propios conocimientos, habilidades y actitudes. El tratamiento, los aparatos y los procedimientos ortopédicos a los cuales el paciente es sometido, generan en el estudiante un importante desgaste emocional, un comportamiento empático y la búsqueda de mecanismos que minimicen el dolor del otro. Todos los aspectos que impregnan la asistencia de los alumnos de Enfermería en Traumatología y Ortopedia, necesitan ser conocidos, para permitir una reevaluación del proceso de enseñanza-aprendizaje.

Descriptores: Enfermería Ortopédica; Atención de Enfermería; Educación Superior.

\section{Introduction}

Orthopedic nursing care is a specialized field related to care provided in the context of diseases, congenital and developmental processes, traumas, metabolic diseases, degenerative diseases, infections and other disorders that affect the musculoskeletal and the joint system and connective tissue support. It includes clinical, surgical and rehabilitation issues, which can be classified as acute, chronic or debilitating(1).

An orthopedic disease progresses slowly and the process is usually painful and compromises the patient's daily activities and quality of life. Orthopedic traumas appear suddenly and may cause important physical, emotional and/or social impairment. Traumas in the musculoskeletal system may trigger events that directly or indirectly compromise other systems and, therefore, should be subject of immediate intervention ${ }^{(2)}$.

In this context, the condition of these patients considerably influences students, determining care 
delivery and the development of specific abilities. In general, such an impact may be either verbally or nonverbally expressed and interferes in learning and the quality of care delivery. An analysis of the students' trajectory does not always clearly reveal the problems that actually interfere with learning and care provided to patients in this specialty, especially when one takes into account that human beings have desires, needs, feelings, fears and also a lack of knowledge.

This study presents some manifestations of the imagination of undergraduate nursing students concerning care provided to patients with trauma and/ or orthopedic disorders.

Identifying the aspects that can influence learning and quality of care delivered in the field of orthopedic nursing can enable reassessing the teaching-learning process in the undergraduate program based on the real needs of students and care provided in this specialty.

\section{Method}

The Social Poetic method was used to produce data in this study in which the subjects are those who develop knowledge through the free expression of their cognitive potential, sensations, emotions, imagination, intuition and reason, promoting artistic creativity in learning, knowledge, research and care delivery ${ }^{(3)}$.

A round of workshops was developed, however data presented here are concerned only with the workshop entitled "student" held on April $27^{\text {th }} 2007$. This workshop was digitally recorded and photographed.

Data were produced by a Researcher-Group composed of 15 students: 14 women and one man, who at the time of data production, were enrolled in the $6^{\text {th }}$ academic semester of the Nursing and Obstetrics Undergraduate program of a public university in the city of Rio de Janeiro, RJ, Brazil.

The development of this project was approved by the Ethics Research Committee at the Francisco de Assis university Hospital at the Anna Nery Nursing School (HESFA-EEAN) protocol $n^{\circ} 025 / 07$. Confidentiality of the study's participants was ensured through the use of one or two capital letters at the end of their testimonies.

The workshop was initiated with the so-called "Affective Coffee", a breakfast characterized as a meeting that promoted physical and emotional proximity among the participants. After a relaxing time, during which the participants were asked to think about themselves as students in the Orthopedic division by making free associations, material was distributed for drawing and collage (white cardboard, crayons, colored pencils, hydrographic pens, colored glue, gouache and brush, colored paper, magazines, scissors, white glue, screws, nails, wire, etc.) for their individual development of "Free Creation Technique"(4) products for them to express images and thoughts that emerged during the relaxing phase.

Afterwards, produced data were immediately shown and analyzed based on individual and collective meanings in order to permit the discovery of the structure of the thought of the group in its heterogeneity ${ }^{(5)}$

This workshop produced posters with abundant images, words and expressions reflecting a positive and welcoming atmosphere, where students agreed to show, write and tell what is authentic for them, permitting us to integrate thoughts and testimonies in a collective process.

Recordings were transcribed and then data analysis was initiated. Data comprised drawings, written records, individual expressions and collective discussions. This material was gathered based on the practice of convergence and placed into thematic categories, which were then more finely grouped into subcategories.

\section{Results}

When the students projected their imagination upon themselves, they did not dissociate it from the image of the patient they cared for. They consider themselves to be students who provide care only because there is a patient to care for and to whom they dedicate themselves. Based on this, the first classification was defined, and data exclusively related to the student were selected from those directly related to the trauma and/or orthopedic patient. This process was required because there were distinct situations, meanings, and understandings among them.

Only some of the categories and subcategories related to the students are presented. Some of the participants' testimonies, in italics and identified by letters, are presented as examples.

\section{Category 1: Care delivered to patients}

\section{Quality care delivery}

This subcategory includes data that indicate experiences are a result of the relation of humanized and committed care that students delivered to patients and their family members.

(...) she (the patient) was crying at the end of the stage because it didn't hurt! We had bathed her, manipulated, turned 
her on her side, changed the sheet and she hadn't felt pain. She was crying because she didn't feel pain... Actually, the entire group started to cry, their eyes filled with tears, everybody discretely left the room, to avoid crying in front of her, it is very good to have this reward, to know that we make a difference. (G)

Being acknowledged by the patient for the quality of care delivered

The students report being acknowledged by patients for the quality of care delivered and their importance to the patient.

(...) she said at the end "thank you very much, thank you very much, thank you very much". We did nothing, nothing! A bath, medication, a bath, changed sheets, but we didn't do anything special! But for that person who completely lost perspective on her life, that was everything. (G)

The students suffer from the patient's condition

Here the students show they sympathize and experience suffering for perceiving the patient's suffering.

(...) when I looked at that person (patient) I said: look, if I had to go through that procedure (traction) to heal my leg and go home, I wouldn't suffer so much. But if I had to go through it and stay here for two months as he is here at the hospital, I couldn't take it... People, I couldn't bear it. I don't think so. (P)

Respect for the patient

This category is related to all the patient's feelings and behaviors and his/her family, which are respected by the students and are related to the patient's needs.

It is with respect that everything happens. It is by respecting the person that you start treating her/him well, gives comfort (...) I think that respect is the best thing we can do for someone. It is being respectful to people. (MS)

Death

The students indicate coping with the end of life and death as an extremely difficult and striking moment.

(...) we fear those wires. I put a lot of blood in my poster though obviously this is not how a person dies. So, you dedicate yourself... I guess that you suffer a lot with someone's death. (G)

\section{Category 2: Knowledge and experience}

Knowledge and experience are sources of the selfconfidence to deliver care

The students indicate that technical-scientific competence and experience are essential to deliver care.

(...) I realized I had to study, that I really had to study,
I realized that if I got there without reading, without having studied something, it'd be worse. It would have been impossible to perform any procedure without studying (...) So, I realized that studying and participating, the care I delivered was different. (L)

\section{Lack of knowledge and experience}

This subcategory addresses the difficulties students had dealing with a lack of the knowledge, experience and skills required in the specialty.

(...) then, at the classroom the professor talked about the splints and things, so I got scared of what to do with the patient, you know. I said "there's no point in studying it if I'll get there and won't know what to do". And then this is a time of distress" (L)

\section{Category 3: The impact of the specialty}

Affinity with the specialty

The results reveal the sort of relationships that are established when there is an affinity or the lack of one with the specialty and the need of specific competencies in the field of knowledge and in relation to the clientele.

If you choose orthopedics, do it because you like it, and do it with love for those who are in need, those who are there depending on us (...), make that these two, eight months are, I won't say pleasurable, but at least bearable for the patient. (MS)

Specialty with good learning experiences

The students recognized that the supervised training in orthopedic nursing was important for their education.

It was really bad until the training ended. And then when it was at the end, I was almost crying: "No! Is it already finishing? Now that it finally kicked in? Now that it got cool?" (...) It was good after the first day, after the shock passed away, everything was all right (...). (L)

\section{Discussion}

The time when students meet the trauma and/ or orthopedic patient in a hospital environment, both unknown to each other until then, requires skills to deal not only with their own emotions and knowledge, but also with others' emotions, which make students feel unprepared to deal with certain situations. The practice is an action that encourages a reflexive process and care should emerge from an eminently dialogical and mutually educational practice, which occurs in the individual and collective sensitization and transformation(6).

Living with and carefully observing the living conditions of patients with trauma and/or orthopedic 
disorders is a teaching opportunity for life and for enabling positive behavioral changes. It shows the importance of this event for the students because it broadens their understanding and responsibility of nursing. These experiences are the result of the relation of care they develop with their patients when knowledge is no longer the purpose of the learning process and becomes a tool serving students to help them to identify the variables present in a situation and potential ways to control them ${ }^{(7)}$.

Hospitals are good spaces for learning because learning processes are linked to work processes. Supervised training at the hospital is a good source of scientific knowledge and provides tools to care for patients and to learn to relate with them and team members ${ }^{(8-9)}$. The students recognize their engagement with the patient and with care that is ethical, of good quality, responsible, and sympathetic. Delivering quality care is seen by the students as the ability to meet the different needs of patients and their families, while planning and implementing orthopedic nursing care. They show themselves to be capable, even if in an intuitive way, of establishing priorities and including not only the biological system but also the psychosocial and spiritual dimensions. It is about perceiving their responsibility to care, considering the consequences of their acts, ensuring integrality, coherence, harmony with what they believe, as well as seeking to base their practice and conduct on ethical and educational principles ${ }^{(10)}$.

In a movement of profound solidarity, the students experience the patient's suffering. This solidarity is seen as a form of caring, the commitment of a being with another. This requires availability, spontaneity, interest and allows the other to feel safe. In these conditions, students are open to understanding, identifying or adhering to their references. They support themselves on empathy, on feeling, recognizing another's unconditional acceptance. In this exercise, they take time to listen to the patient and monitor their condition. Based on dialogue, an encounter with another is possible, enabling action, reflection, and guidance for a world that requires transformation and humanization.

There is a strong tendency among students "to put themselves in the shoes" of those who they care for. It seems they care for the patient, while living in and appropriating the patient's world. Somehow, by making this very world a movement of action and reaction, they care for the patient the way they would like to be cared for or do what they would like people to do for them if they were in the same situation. Part of the pedagogical process is to lead students interact with the reality in which they find themselves and transform themselves based on the experiences they have so that they grow as individuals and future professionals. This empathetic feeling, the result of an impulse to put themselves in someone else's situation, is a therapeutic way of being and favors recovery and wellbeing because it encourages them to be committed to life and to another person.

The possibility of death in an orthopedic division, which may occur suddenly or by slow progression, seems to derail students. These situations of the end of life and occurrence of death cause great suffering and nonconformity and are indicated as a time profoundly difficult because these situations arouse intense feelings, especially of powerlessness and an inability to impede death. It is difficult for these young individuals to understand terminality because they see death as a punishment or injustice and not as a stage in the process of being human. Severe, terminal diseases and imminent death are a reality for trauma and/or orthopedic patients and highlight the students' personalities leading them to reconsider concepts, personal values and academic practices. Despite their lack of experience, and because they do not know how to deal with their own feelings, they understand that the dialogue, reception, comfort and clarification they provide are the best and most correct way for the patient and family to cope with terminality. It is important to introduce a critical-reflexive view of the death process and dying in academic education so that these professionals are able to deal with death naturally without the sensation of personal failure and frustration ${ }^{(11)}$.

The students understand that good care is respectful and respect for the patient refers to the person and quality of care in a condition of being entirely with another, in a dynamic presence that transforms and helps another to transcend his/her condition of pain and suffering(6). This wisdom is applied with a sensitivity that fits in the perspectives of care, which recognizes the one who provides care and the one who receives care to be in a constant relation of exchange ${ }^{(12)}$. It is this sensitivity that causes them to associate the most varied feelings with attitude and behavior aimed to promote the patients' wellbeing. When they realize the difference they do make in the lives of these people, they are encouraged to seek improved quality care. The nurses are able to locate the patient in the subjective and social context of life, which is not always valued in a hospital environment, and are acknowledged by their knowledge, technical skills, and the complexity of what they do in different abilities. 
Orthopedic supervised training was considered to be significant in the education of future nurses. Among the diverse learning aspects of college students, the development of their intellectual, human and professional abilities stands out in addition to attitudes and values integrating professional life ${ }^{(13)}$. Hence, it is established that a well-structured base of knowledge is essential for providing safe and efficient care in the orthopedic nursing field, meaning that one cannot provide care to this type of clientele without previous preparation.

The encounter of nursing students with the diverse facets of care enables them to include the new through the acquisition of knowledge and the experience of apprehension and fear, which are present when one is coping with the new ${ }^{(12)}$. Good and bad experiences enrich them as individuals and as future professionals without their realizing it. The internalization of care as value requires a sequential process that is developed over time while students progress in their education, from a guided to an independent practice.

Students consider knowledge and experience to be essential to making them feel self-confident in providing good care. Undoubtedly, the most useful learning in the modern world is that learning that enables continuous opportunities to acquire experience and to incorporate processes of change. When we acquire experiences, we obtain achievements that are then expressed in our secure attitudes demonstrated through actions where acquired knowledge is implemented, in order to permit students gradually to become autonomous individuals(12). In a liberating education they become critical, independent, inquisitive, capable individuals with the tools to reflect and intervene upon their realities ${ }^{(14)}$. Therefore, it is the role of the student to orient their desire to learn taking into account their potentialities and aptitudes.

Developing such complex abilities to provide care within the orthopedic nursing field requires the ability to use and manipulate cognitive skills to help one to reflect on different situations, analyze, exam, criticize and systematize information $^{(7)}$. It means that for students to achieve providing quality care they need to constantly reflect on their knowledge, skills and attitudes, so as to become capable to maximize strategies to solve the problems they face.

When students begin their education, they start defining care based on a personal reference point. As the program progresses, the students develop a broad definition of care applied to their patients, and their practice serves as a positive reinforcement when they provide appropriate care. Hence, the experiences in the orthopedic nursing field broaden their understanding concerning their role in nursing care and develop qualities and abilities to identify how the patient defines and receives care. At this point in their education, the relationships students establish among several concepts: of nursing is; what it is to be a nurse; and their role as human beings. Through all of these they identify the importance of quality care in orthopedic nursing and its deficiencies.

Having affinity with the orthopedic nursing field directly influences care and personal satisfaction. Even though they recognize the field's complexity and physical exhaustion, students see themselves as able to care for patients with trauma and/or orthopedic disorders after acquiring experience through supervised training. They understand that when one has no interest in the specialty, care delivery and the exercise of the profession are accompanied by tension, distress, and suffering in the face of the responsibility imposed on nurses and, then, acknowledge that specific knowledge concerning the field has impact on the quality of care. This affinity is identified based on personal interests, technical and specific knowledge related to their clientele. Since the development of concept and conceptions is a process that occurs over the program based on a daily routine, when the individual recognizes interest in the field, the natural tendency, according to students, is to act with technical competence, to assume a reflective, critical, creative attitude and constantly seek to update their knowledge.

The training of future nurses should ensure an education focused on citizenship and discernment in order to ensure that humanized and quality care is delivered to patients. One should rethink the way nursing professionals are being educated, perceiving students as beings with imaginative and creative capacity able to recreate their reality according to their needs, in a pedagogical search that take into account their potentialities, contributing to the education of better qualified professionals, enabling them to recover their needs, value their context and individuality, minimizing flaws and inequality stemming from health and educational policies, as well as to contribute to improving the quality of nursing care and college education ${ }^{(15)}$

\section{Conclusion}

This study revealed that care delivered by undergraduate nursing students is the result of a relation of care that emerges from the students' sensitivity toward their patients. It is a product of continuous 
reflection on the different situations they experience, about their own knowledge, skills and attitudes, making them capable to establish strategies to solve problems. These students deliver quality, humanized care that goes beyond the physical and includes the psychosocial, spiritual and environmental dimensions, and are also engaged, ethical, responsible and sympathetic. Being acknowledged for providing quality care is essential for students because it gives them satisfaction and positive reinforcement to their dedication and effort. Orthopedic treatment, equipment, and procedures-which cause great suffering, the possibility of death, of physical impairment, and of compromising the patients' and their families' life routines-generate great distress in students, trigger empathic feelings and encourage them to seek out the means to minimize patients' pain and to ensure quality care in this specialty.

The classical strategies of banking* education do not reduce the fear and insecurity one may have when delivering care in the orthopedic nursing field during the undergraduate program. For this reason, these strategies should be revised. All the aspects that permeate care provided by students in the orthopedic nursing field need to be identified to enable a reassessment of the teaching-learning process, based on the real needs of students and care in this specialty.

${ }^{*}$ T.N.: Banking education is a metaphor that refers to students being empty recipients in which educators must deposit knowledge.

\section{References}

1. Cameron LE. Enfermagem Traumato-Ortopédica. Programa de Atualização de Enfermagem: saúde do adulto (PROENF) Ciclo 5, Módulo 1. Porto Alegre (RS): Artmed/Panamericana Editora; 2010. p. 45-85.

2. Cameron LE, Araújo STC. Vision as an instrument of perception in trauma and orthopedic nursing care. Rev Esc Enferm USP. 2011;45(1):95-9.

3. Fleuri, RM. Prefácio. In: Santos I, Gauthier J, Figueiredo NMA, Petit SH. Prática da Pesquisa nas Ciências Humanas e Sociais: Abordagem Sociopoética. São Paulo: Editora Atheneu; 2005.

4. Antunes $C$. Manual de técnicas de dinâmica de grupo, de sensibilização, de ludopedagogia. 20a ed. Petrópolis (RJ): Vozes; 2000
5. Petit SH, Gauthier JZ, Santos I, Figueiredo NMA. Introdução: Introduzindo a Sociopoética. In: Santos I, Gauthier J, Figueiredo NMA, Petit SH. Prática da Pesquisa nas Ciências Humanas e Sociais: Abordagem Sociopoética. São Paulo: Editora Atheneu; 2005. p. 1-16. 6. Silva AL. Cuidado como momento de encontro e troca. Anais do 500 Congresso Brasileiro de Enfermagem. Florianópolis; 2000. p. 14-9.

7. Stedile NLR, Friendlander MR. Metacognição e ensino de enfermagem: uma combinação possível? Rev. LatinoAm. Enfermagem. dez 2003;11(6):792-9.

8. Shinyashiki GT, Mendes IAC, Trevizan MA, Day RA. Professional socialization: students becoming nurses. Rev. Latino-Am. Enfermagem. ago 2006;14(4):601-7.

9. Fagundes NC, Burnham TF Discutindo a relação entre espaço e aprendizagem na formação de profissionais de saúde. Interface. 2005;9(16):105-14.

10. Sordi MRL, Bagnato MHS. Subsídios para uma formação profissional crítico-reflexiva na área de saúde: o desafio da virada do século. Rev. Latino-Am. Enfermagem. abr 1998;6(2):83-8.

11. Santos JL, Bueno SMV. Educação para a morte a docentes e discentes de enfermagem: revisão documental da literatura científica. Rev. esc. enferm. USP. $2011 ; 45(1)$ : 272-276.

12. Camacho ACLF, Espírito Santo FH. Refletindo sobre o cuidar e o ensinar na Enfermagem. Rev. Latino-Am. Enfermagem. jan 2001;9(1):13-7.

13. Masetto MT Docência universitária: repensando a aula. In: Teodoro A, Vasconcelos $\mathrm{ML}$, organizadores. Ensinar e aprender no ensino superior: por uma epistemologia da curiosidade na formação universitária. 2a ed. São Paulo (SP): Editora Mackenzie/Cortez; 2005. p. 79-107.

14. Miranda KCL, Barroso MGT. A contribuição de Paulo Freire à prática e educação crítica em enfermagem. Rev. Latino-Am. Enfermagem. ago 2004;12(4):631-5.

15. Mostardeiro SCTS. Refletindo sobre a formação do enfermeiro: a prática docente a partir do imaginário pedagógico. Esc Anna Nery. 2004;8(1):21-8.

Received: July $11^{\text {th }} 2010$ Accepted: Sept. 20th 2011 